\title{
Pengaruh Kualitas Pelayanan Terhadap Kepuasan Pelanggan (Studi Kasus Pada Kolam Renang Bengawan Solo Pangkalan Brandan)
}

\author{
Nasib \\ Program Studi Manajemen Pemasaran, Politeknik Unggul LP3M, Medan, Indonesia \\ Email: nasibwibowo02@gmail.com
}

\begin{abstract}
ABSTRAK
Penelitian ini bertujuan untuk mengetahui pengaruh kualitas pelayanan terhadap kepuasan pelanggan. Populasi dalam penelitian ini adalah pengunjung di kolam Bengawan Solo Pangkalan Brandan yang berjumlah 75 orang sedangkan teknik penentuan sampel dengan sampling non propability oleh Accidental Sampling, teknik penentuan sampel menggunakan accidental sampling. Jenis penelitian ini adalah penelitian kausal, berguna untuk menganalisis bagaimana variabel mempengaruhi variabel lain, dan juga berguna dalam penelitian eksperimental dimana variabel bebas diperlakukan pada variabel dependen secara langsung. Hasil analisis regresi sederhana adalah $\mathrm{Y}=4.764+0.198 \mathrm{X} 1+0,096 \mathrm{X} 2+0,425 \mathrm{X} 3+0,268 \mathrm{X} 4+0,602 \mathrm{X} 5+\mathrm{e}$ dimana variabel bukti fisik, reliabilitas, daya tanggap, assurance dan empati berpengaruh positif dan signifikan terhadap kepuasan pelanggan pada Bengawan Solo. kolam renang. Hasil pengujian (t) atau uji parsial menunjukkan bahwa semua variabel independen bukti fisik, reliabilitas, daya tanggap, kepastian dan empati memiliki pengaruh positif dan signifikan terhadap kepuasan pelanggan. Hasil uji determinasi (R2) adalah 0804 (80,4\%). Sehingga dapat dikatakan bahwa variasi variabel terikat sebesar $80,4 \%$ yaitu bukti fisik, reliabilitas, daya tanggap, assurance dan empathy dalam model dapat menjelaskan kepuasan pengunjung sedangkan sisanya 19,6\% dipengaruhi oleh variabel lain diluar model.
\end{abstract}

Kata Kunci: Bentuk fisik, kehandalan, taya tanggap, jaminan, empati, kepuasan pelanggan

\section{Effect of Service Quality on Customer Satisfaction (Case Study In Bengawan Solo swimmingpool, Pangkalan Brandan)}

\begin{abstract}
This study aims to determine the effect of service quality on customer satisfaction. Population in this research is visitor at pool of Bengawan Solo Pangkalan Brandan which amounts to 75 people while the technique of determination of sample by non propability sampling by Accidental Sampling. With sample determination techniques for respondents who happen to be encountered by researchers at the time of data collection. This type of research is a causal research, useful for analyzing how variable affects other variables, and also useful in experimental research in which the independent variables are treated in the dependent variable directly. The result of simple regression analysis is $Y=4.764+0.198 X 1+0,096 X 2+0,425 X 3+0,268 X 4+0,602 X 5+e$ which variable of physical evidence, reliability, responsiveness, assurance and empathy positive and significant influence to customer satisfaction at Bengawan Solo swimming pool. The test results $(t)$ or partial test indicate that all the independent variables of physical evidence, reliability, responsiveness, assurance and empathy have a positive and significant effect on customer satisfaction. The result of determination test (R2) is $0804(80.4 \%)$. So it can be said that $80.4 \%$ variation of bound variables that is physical evidence, reliability, responsiveness, assurance and empathy in the model can explain the satisfaction of the visitors while the rest of $19.6 \%$ influenced by other variables outside the model.
\end{abstract}

Keywords: Tangible, Reliability, Responsiveness, Assurance, Empathy, Customer Satisfaction

How to cite:

Nasib. (2017). Pengaruh Kualitas Pelayanan Terhadap Kepuasan Pelanggan (Studi Kasus Pada Kolam Renang Bengawan Solo Pangkalan Brandan). Jurnal Ilmiah Manajemen \& Bisnis, 18(1), 30-44. 


\section{PENDAHULUAN}

Perusahaan yang bergerak pada bidang jasa, rasa kepuasan pelanggan pelanggan ini merupakan suatu rasa perasaan yang dirasakan pelanggan buah dari pelayanan yang ia dapatkan. Rasa kepuasan ini memiliki tingkat yang berbeda diantara para pelanggan. Sehingga sebagai penyedia jasa perusahaan harus dapat memberikan kualitas pelayanan yang berbeda diantara para pelanggan. Apabila hal ini telah perusahaan dapat maka perusahaan dapat mmperoleh tingkat profitabilitas yang lebih mapan guna menutupi segala biaya yang harus ia keluarkan serta meningkatkan kesejahteraan para pemilik pemangku kepentingan jabatan (stakeholder).

Rasa kepuasan yang dialami oleh pelanggan tentu akan memberikan kontribusi bagi pihak internal suatu organisasi. Hal ini bisa dilihat dari banyaknya keluhan yang dirasakan oleh pelanggan ataupun saran - saran serta kritikan yang menjadikan bahan masukan organisasi dalam menetapkan strategi dalam menghadapi dunia persaingan. Keluhan maupun komplain sebaiknya harus diolah dan dijadikan bahan pertimbangan dalam mengambil sebuah keputusan strategis yang mengarahkan kepada pencapian dari tujuan organisasi tersebut. Rasa kepuasan yang telah didapatkan oleh pelanggan serta pelayanan yang telah diberikan oleh organisasi merupakan suatu rasa yang diharapkan dengan rasa yang dirasakannya. Apa bila rasa kepuasan melebihi dari apa yang diharapkan inilah yang disebut dengan kepuasan dan sebaliknya apa bila konsumen merasa rasa kepuasan kurang dari yang diharapkannya dinamakan ketidakpuasan (Situmorong, 2011:206).

Rasa puas yang didapatkan seorang pelanggan tentunya akan menjadikan obor bagi perusahaan yang kiranya menjadikan promosi word of month yang menjadikan keunggulan tersendiri bagi perusahaan tersebut tersebut. Sebaliknya jika perusahaan tidak dapat menciptakan rasa kepuasan didalam benak pelanggan pastilah akan menimbulkan sebuah rasa yang membuatkan jenuh serta berdampak pada pengalaman. Ini berarti perusahaan telah gagal dalam menjadikan word of mounth sehingga dapat dipastikan menjadikan ancaman serta masalah tersendiri bagi internal perusahaan tersebut Kotler et.al dalam Tjiptono (2008:169)

Banyak faktor yang mempengaruhi dari kepuasan pelanggan diantaranya menurut Tjiptono (2007:159) menjelaskan bahwa rasa ketidakpuasan pelanggan diakibatkan oleh faktor internal dan faktor eksternal. Kedua faktor tersebut dianggap kerusial dalam mencapai kepuasan yang dirasakan oleh konsumen ataupun pelanggan. Berikut akan dijabarkan pengertian dari kedua faktor tersebut yakni faktor internal dan faktor eksternal. Faktr internal merupakan faktor yang terdapat pada diri pelanggan, misalnya motivasi pelanggan dalam membeli, prsepsi pelanggan akan kualitas pelayanan yang akan ia dapat dan sebagainya. Sedangan faktor eksternal ini merupakan kebalikan dari faktor internal, yaitu suatu faktor yang terdapat diluar diri pelanggan. misalnya demografi yang akan mempengaruhi pelanggan dalam pembelian.

Menurut Kotler didalam Laksana (2008:85) kualitas pelayanan (Service Quality) adalah setiap tindakan atau kegiatan yang dapat ditawarkan oleh satu pihak kepada pihak lain, yang pada dasarnya tidak berwujud dan tidak mengakibatkan kepemilikan apapun. Istilah kualitas pelayanan (ServQual) merupakan satu model yang banyak diterapkan dalam beberapa industri jasa dalam mengukur rasa kepuasan pelanggan. Kualitas pelayanan ini merupakan variabel yang kompleks dimana kualitas pelayanan memiliki dimensi kualitas pelayanan. Sedangkan menurut Parasuraman didalam Jasfar (2005:51) ada 
lima dimensi dari kualitas pelayanan, yaitu: (1) Reliability (kehandalan), yaitu kemampuan untuk memberikan pelayanan yang dijanjikan dengan tepat (accurately) dan kemampuan untuk dipercaya (dependability), terutama memberikan jasa secara tepat waktu (ontime), dengan cara yang sesuai dengan jadwal yang telah dijanjikan dan tanpa melakukan kesalahan setiap kali, (2) Responsiveness (daya tanggap), yaitu kemampuan atau keinginan para karyawan untuk membantu dan memberikan jasa yang dibutuhkan konsumen. Membiarkan konsumen menunggu, terutamam tanpa alasan yang jelas akan menimbulkan kesan negatif yang tidak seharusnya terjadi. Kecuali apabila kesalahan ini ditanggapi dengan cepat, maka akan menjadi sesuatu yang berkesan dan menjadi pengalaman yang menyenangkan. Misalnya, karena keterlambatan keberangkatan pesawat, penumpang diberikan makanan dan minuman, (3) Assurance (jaminan), meliputi pengetahuan, kemampuan, ramah, sopan, dan sifat dapat dipercaya dari kontak personel untuk menghilangkan sifat keragu - raguan konsumen dan merasa terbebas dari bahaya dan resiko, (4) Empathy (empati), yang meliputi sikap personel maupun perusahaan untuk memahami kebutuhan maupun kesulitan, konsumen, komunikasi yang baik, perhatian pribadi, kemudahan dalam melakukan komunikasi atau hubungan, (5) Tangible (produk-produk fisik), tersedianya fasilitas fisik, perlengkapan dan saranan komunikasi, dan lain - lain yang dapat dan harus ada dalam proses jasa. Penilai terhadap dimensi ini dapat diperluas dalam bentuk hubungan dengan konsumen yang lain pengguna jasa, misalnya keributan yang dilakukan oleh tamu lain di hotel.

Kolam renang Bengawan Solo merupakan salah satu perusahaan yang bergerak pada bidang jasa, yaitu penyediaan jasa kolam renang di kota Pangkalan Brandan. Kolam renang Bengawan Solo dituntut untuk terus meningkatkan kualitas pelayanan terhadap para pengunjung. Fakta yang terjadi selama ini masih banyaknya keluhan pelanggan atas pelayanan yang diberikan. Misalnya pelanggan merasa komplain terhadap kualitas pelayanan. Selama ini pelayanan yang banyak dikeluhkan oleh para pengunjung yaitu kurang ramah kepada para pelanggan, sarana dan prasarana yang kurang baik yang ditandai dengan sulitnya pelanggan dalam memparkirnya sepeda motor atau mobilnya serta kamar ganti yang dirasa masih kotor dan bau, parkir yang tidak nyaman, perhatian yang kurang baik dari karyawan.

\section{KAJIAN TEORI \\ Kepuasan Pelanggan}

Menurut Yuri et.al (2013:114) kepuasan didefinisikan sebagai tingkat pernyataan perasaan seseorang terhadap kinerja produk yang dirasakan jika dibandingkan dengan yang diharapkan. Kemudian Menurut Tjiptono (2008:169): "Kepuasan pelanggan adalah evaluasi purnabeli keseluruhan yang membandingkan persepsi terhadap kinerja produk dengan ekspektasi prapembelian". Sedangkan menurut Oliver di dalam Supranti (2006:233): mendefinisikan "Kepuasan pelanggan adalah tingkat perasaan seseorang setelah membandingkan kinerja/hasil yang dirasakannya dengan harapannya". Lain halnya menurut Garpersz di dalam Laksana (2008:96):"Kepuasan yaitu sebagai suatu keadaan di mana kebutuhan dan keinginan dengan harapan pelanggan dapat terpenuhi melalui produk yang dikomsumsi”. Dapat disimpulkan bahwa kepuasan pelanggan merupakan suatu perasaan pelanggan dimana antara apa yang diharapkan dengan apa yang dirasakan dari kualitas pelayanan dan produk yang telah ia dapat sesuai atau tidak dengan persepsinya. Jika sebuah kepuasan pelanggan ini dirasakan sangat penting, maka sudah selayaknya kepuasan pelanggan terus dan terus dipertahankan dari waktu ke waktu. 
Kepuasan pelanggan ini harus diukur atau dinilai apakah selama ini kualitas pelayanan dan kualitas yang diberikan perusahaan kepada para pelanggan sudah sesuai harapan atau belum. Menurut Tjiptono (2008:175): “Ada empat metode yang digunakan untuk mengukur kepuasan seorang pelanggan, yakni”:

a. Sistem keluhan dan saran, seperti kotak saran di lokasi - lokasistrategis, kartu pos berprangko, saluran telepon bebas pulsa, website, email, fax, blog dan lain-lain.

b. Ghost shopping mistery yaitu salah satu bentuk riset observasi partisasipasi yang memakai jasa orang-orang yang menyamar sebagai pelanggan perusahaan dan pesaing sembari mengamati secara rinci aspek-aspek pelayanan kualitas produk.

c. Lost customer analysis yakniu menghubungi atau mewawancari para pelanggan yang beralih pemasok dalam rangka memahami dan melakukan perbaikan pelayanan.

d. Survey kepuasan pelanggan, baik via pos, telepon, email, website, blog, maupuntatapmukalangsung.

Ada beberapa manfaat yang akan didapatkan oleh perusahaan jika mampu menciptakan rasa kepuasan pelanggan. Manfaat ini bukan hanya akan dinikmati dengan nilai ekonomis melainkan juga seperti kepuasan tersendiri dari seorang pimpinan perusahaan. Menurut Tjiptono (2008:169) kepuasan pelanggan juga berpotensi memberikan sejumlah manfaat spesifik diantaranya:

a. Berdampak positif terhadap loyalitas pelanggan

b. Berpotensi menjadi sumber pendapatan masa depan, terutama melalui pembelian ulang, cross - selling dan up - selling

c. Menekan biaya transaksi pelanggan dimasa depan, terutama biaya - biaya komunikasi pemasaran, penjualan dan layanan pelanggan d. Menekan polatilitas dan resiko berkenaan dengan prediksi aliran kas masa depan

e. Meningkatkan toleransi harga, terutama kesediaan pelanggan untuk membayar harga premium dan pelanggan cenderung tidak mudah tergoda untuk beralih pemasok

f. Menumbuhkan rekomendasi getok tular positif

g. Pelanggan cenderung lebih reseptif terhadap product - line extensions, brand - extensions dan new add - on services yang ditawarkan perusahaan.

h. Meningkatkan Bargaining Power relatif perusahaan terhadap jaringan pemasok, mitra bisnis dan saluran distribusi.

\section{Kualitas Pelayanan}

Pelayanan atau jasa adalah setiap tindakan atau kegiatan aktivitas yang dapat ditawarkan oleh suatu pihak kepada pihak lain, yang pada dasarnya tidak berwujud dan tidak mengakibatkan kepemilikan apapun (Kotler dalam Laksana (2008:85). Kemudian menurut Jasfar (2005:17):“Jasa atau pelayanan adalah setiap tindakan atau aktivitas dan bukan benda, yang dapat ditawarkan oleh suatu pihak kepada pihak lain, yang pada dasarnya bersifat tangible (tidak berwujud fisik), konsumen terlibat secara aktif dalam proses produksi dan tidak menghasilkan kepemilikan sesuatu." Sedangkan menurut Zeithsmlet.al di dalam Daryanto (2011:237): "Jasa adalah seluruh aktivitas ekonomi dengan output selain produk dalam pengertian fisik, dikonsumsi dan diproduksi pada saat bersamaan, memberikan nilai tambah dan secara prinsip tidak berwujud bagi pembeli pertamanya."

Menurut Parasuraman didalam Tjiptono (2008:108) mengidentifikasikan 10 dimensi kualitas pelayanan, yaitu:

a. Reliabilitas, mencakup dua aspek utama, yaitu konsistensi kinerja (performance) dan sikap dipercaya (dependability).

b. Responsivitas atau daya tanggap, yaitu kesediaan dan kesiapan para karyawan 
untuk membantu dan melayani para pelanggan dengan segera. $\backslash$

c. Kompetensi, yaitu penguasaan keterampilan dan pengetahuan yang dibutuhkan agar dapat melayani sesuai dengan kebutuhan pelanggan..

d. Akses, meliputi kemudahan untuk dihubungi atau ditemui (approachability) dan kemudahan kontak.

e. Kesopanan (courtesy), meliputi sikap santun, respek, atensi, dan keramahan para karyawan kontak (seperti resepsionis, operator telepon, bell personal, teller bank, dan lain-lain).

f. Komunikasi, artinya menyampaikan informasi kepada para pelanggan dalam bahasa yang mudah mereka pahami, serta selalu mendengarkan saran dan keluhan pelanggan.

g. Kredibilitas, yaitu sikap jujur dan dapat dipercaya. Kredibilitas mencangkup nama perusahaan, reputasi perusahaan, karakter pribadi karyawan kontak, dan interaksi dengan pelanggan (hard selling versus soft selling approach).

h. Keamanan (security) yaitu bebas dari bahaya, resiko atau keragu - raguan. Termasuk didalamnya adalah keamanan secara fisik (phisikal safety), keamanan financial (financial security), privasi, dan kerahasiaan (confidentiality).

i. Kemampuan memahami pelanggan, yaitu berupaya memahami pelanggan dan kebutuhan spesifik mereka, memberikan perhatian individual, dan mengenal pelanggan reguler.

j. Bukti fisik (tangible), meliputi penampilan fisik, peralatan personel, dan bahan-bahan komunikasi perusahaan (seperti kartu bisnis, kop surat dan lain-lain).

Menurut Tjiptono (2008:96) ada tujuh penyebab baik buruknya kualitas layanan, yaitu:
1. Produksi dan konsumsi yang terjadi secara simultan. Salah satu karakteristik unit jasa/layanan adalah inseparability, artinya jasa diproduksi dan dikonsumsi pada saat bersamaan. Beberapa kelemahan yang mungkin ada pada karyawan dan mungkin berdampak negatif terhadap persepsi kualitas meliputi:

a. Tidak terampil dalam melayani pelanggan.

b. Cara berpakaian karyawan kurang sesuai dengan konteks.

c. Tutur kata karyawan kurang sopan atau bahkan menyebalkan.

d. Bau badan karyawan mengganggu kenyamanan pelanggan.

e. Karyawan selalu cemberut atau pasang tampang "angker"

2. Intensitas tenaga kerja yang tinggi

Keterlibatan karyawan secara intensif dalam penyampaian layanan dapat pula menimbulkan masalah kualitas, yaitu berupa tingginya variabilitas layanan yang dihasilkan. Faktor-faktor yang bisa mempengaruhi antara lain : upah rendah (umumnya karyawan yang melayani atau berinteraksi langsung dengan pelanggan memiliki tingkat pendidikan dan upah yang paling rendah dalam sebuah perusahaan), pelatihan yang kurang memadai atau bahkan tidak sesuai dengan kebutuhan organisasi, tingkat perputaran karyawan terlalu tinggi, motivasi kerja karyawan rendah, dan lain - lain.

3. Dukungan terhadap pelanggan internal kurang memadai

Karyawan front line merupakan ujung tombak sistem penyampaian layanan. Bukan saja mereka itu adalah "wajah" organisasi, namun acap kali meremehkan cerminan "jasa" yang dipersepsikan konsumen. 
4. Gap komunikasi

Tak dapat dipungkiri lagi bahwa komunikasi merupakan faktor esensial dalam menjalin kontak dan relasi dengan pelanggan. Bila terjadi gap komunikasi, maka bisa timbul penilaian atau persepsi negatif terhadap kualitas pelayanan. Gap - gap komunikasi berupa:

a. Penyedia layanan memberikan janji berlebihan, sehingga tidak mampu memenuhinya.

b. Penyedia layanan tidak bisa selalu menyajikan informasi terbaru kepada para pelanggan, misalnya yang berkaitan dengan perubahan prosedur / aturan, perubahan susunan barang di rak pajangan swalayan, perubahan kemasan, perubahan harga, dan lain-lain.

c. Pesan komunikasi penyedia layanan tidak dipahami pelanggan.

d. Penyedia layanan tidak memperhatikan atau tidak menindaklanjuti keluhan dan/atau saran pelanggan.

4. Memperlakukan semua pelanggan dengan cara yang sama. Pelanggan merupakan individu unik dengan preferensi, perasaan, dan emosi masing - masing. Dalam hal interaksi dengan penyedia layanan, tidak semua pelanggan bersedia menerima layanan yang seragam (standardized service). Sering terjadi ada pelanggan yang menginginkan atau bahkan menuntut layanan yang sifatnya personal dan berbeda dengan pelanggan lain. Hal ini memunculkan tantangan bagi penyedia layanan dalam hal kemampuan memahami kebutuhan spesifik pelanggan individu dan memahami perasaan pelanggan terhadap penyedia layanan spesifik yang mereka terima.

5. Perluasan atau pengembangan layanan secara berlebihan
Disatu sisi, mengintroduksi layanan baru atau menyempurnakan layanan lama dapat meningkatkan peluang pertumbuhan bisnis dan menghindari terjadinya layanan yang buruk. Disisi lain, bila terlampau banyak layanan baru dan tambahan terhadap layanan yang sudah ada, hasil yang didapatkan belum tentu optimal, bahkan tidak tertutup kemungkinan timbul masalahmasalah seputar standar kualitas layanan.

6. Visi bisnis jangka pendek

Visi jangka pendek (misalnya, orientasi pada pencapaian target penjualan dan laba tahunan, penghematan biaya sebesar-besarnya, peningkatan produktivitas tahunan, dan lain-lain) bisa merusak kualitas layanan yang sedang dibentuk untuk jangka panjang. Sebagai contoh sebuah bank untuk menekan biaya dengan cara menutup sebagian kantor cabangnya akan mengurangi tingkat akses bagi para nasabahnya, yang pada gilirannya bisa menimbulkan ketidakpuasan pelanggan dan persepsi negatif terhadap kualitas pelayanan bank bersangkutan.

\section{Kerangka Konseptual}

Pada hakekatnya kepuasan konsumen merupakan suatu hal yang harus ditingkat dari waktu ke waktu, hal ini disebabkan bahwa rasa kepuasan yang dirasakan oleh setiap konsumen bersifat dinamis yang semua tersebut dapat berubah sesuai dengan faktor internal ataupun faktor eksternal yang ada pada diri konsumen. Sebuah layanan yang memiliki layanan diferensial diantara para pesaing jelaslah perusahaan tersebut dapat tumpuh ditengah-tengah persaingan yang begitu tajam. Banyak upaya yang dapat ditingkatkan dalam meningkatkan kepuasan konsumen. Salah satunya yakni 
dengan memberikan pelayanan yang prima. Kualitas pelayanan merupakan salah satu upaya yang dapat dilakukan perusahaan dalam menciptakan rasa kepuasan. Kualitas pelayanan dapat ditingkatkan melalui dimenasi kualitas pelayanan diantaranya bukti fisik, kehandalan, daya tanggap, jaminan dan empati.

Bukti fisik suatu pelayanan dapat ditingkatkan melalui upaya dalam hal penyediaan sarana dan prasarana. Kualitas air dalam kolam renang yang bersih, area parkir yang nyaman, toilet dan ruang ganti yang bersih. Upaya yang dapat dilakukan dalam meningkatkan kepuasan konsumen melalui kehandalan yakni memberikan kepastiian layanan kepada konsumen. Jam buka dan tutup kolam renang, pemberian janji berupa potongan harga tiket merupakan contoh meningkatkan kehandalan layanan. Daya tanggap layanan ini juga harus ditingkatkan misalnya saja dengan respon karyawan dan pimpinan kolam renang dalam menerima segala keluhan dan komplain dari pengunjung kolam renang yang ada serta memberikan solusi atas masalah yang dihadapi oleh pengunjung kolam renang. Terakhir empati layanan dapat ditingkatkan melalui rasa simpati para karyawan dan pimpinan terhadap para pengunjung. Misal memberikan perhatian khusus agar rasa keakraban diantara pengnjung kolam renang dan karyawan menjadi lebih akrab baik di luar maupun di dalam kolam renang.

\section{Hipotesis}

Berdasarkan pemaparan kajian teori dan latar belakang masalah maka penulis memberikan hipotesis sebagai berikut :

1. Terdapat pengaruh positif dan signifikan bukti fisik terhadap kepuasan pelanggan pada kolam renang Bengawan Solo Pangkalan Brandan Langkat?

2. Terdapat pengaruh positif dan signifikan kehandalan terhadap kepuasan pelanggan pada kolam renang Bengawan Solo Pangkalan Brandan Langkat?
3. Terdapat pengaruh positif dan signifikan daya tanggap terhadap kepuasan pelanggan pada kolam renang Bengawan Solo Pangkalan Brandan Langkat?

4. Terdapat pengaruh positif dan signifikan jaminan terhadap kepuasan pelanggan pada kolam renang Bengawan Solo Pangkalan Brandan Langkat?

5. Terdapat pengaruh positif dan signifikan empati terhadap kepuasan pelanggan pada kolam renang Bengawan Solo Pangkalan Brandan Langkat?

6. Terdapat pengaruh positif dan signifikan bukti fisik, kehandalan, daya tanggap, jaminan dan empati terhadap kepuasan pelanggan pada kolam renang Bengawan Solo Pangkalan Brandan Langkat?

\section{METODE}

Jenis penelitian ini merupakan penelitian asosiatif atau kausal, yang bertujuan untuk mengetahui derajat hubungan dan pola/bentuk pengaruh antar dua variebel atau lebih, dimana dengan penelitian ini maka akan dibangun suatu teori yang berfungsi untuk menjelaskan, meramalkan dan mengontrol suatu gejala" Menurut Rusiadi (2013:14) dengan pendeketan kuantitatif dengan teknik analisis data menggunakan regresi linier berganda. Populasi dalam penelitian ini adalah pengunjung pada kolam renang Bengawan Solo Pangkalan Brandan Langkat yang berjumlah 75 orang. Teknik pengambilan sampel dalam penelitian ini dengan metode Non propability sampling dengan cara accidental sampling yaitu sampel/responden yang kebetulan ditemui oleh peneliti pada saat pengumpulan data. Sedangkan cara pengambilan sampel dengan menggunakan teknik sampel jenuh yang merupakan seluruh populasi dapat dijadikan sampel mengingat bahwa jumlah populasi yang tidak diketahui. Jadi sampel dalam penelitian ini yakni berjumlah 75 responden.

\section{HASIL DAN PEMBAHASAN Uji Validitas}


Menurut Helmi (2011:79) jika nilai Corrected Item - Total Correlation lebih besar dari 0,361 maka butir dinyatakan valid. Data penelitian dinyatakan valid jika memiliki kriteria dengan membandingkan nilai Corrected Item - Total Correlation dengan $r$ tabel $(0,361)$. Berdasarkan Uji validitas menggunakan SPSS dapat diketahui bahwa seluruh komponen variable Bukti Fisik $\left(\mathrm{X}_{1}\right)$, Validitas Kehandalan $\left(\mathrm{X}_{2}\right)$, Daya Tanggap (X3), Jaminan (X4), Empati (X5) dan Kepuasan Pengunjung (Y) dapat dinyatakan $\mathrm{r}$ hitung $>$ rtabel $(0,361)$. Sehingga seluruh butir pertanyaan yang valid akan diuji reliabilitasnya. Uji reliabilitas menggunakan Cronbach Alpha, dimana nilai Cronbach Alpha untuk seluruh komponen variabel butir pertanyaan melebihi angka 0 ,6 sehingga butir-butir pertanyaan dalam penelitian ini sudah reliabel dan dapat diteruskan dapat melakukan pengolahan data.

\section{Uji Asumsi Klasik \\ Uji Normalitas Data}

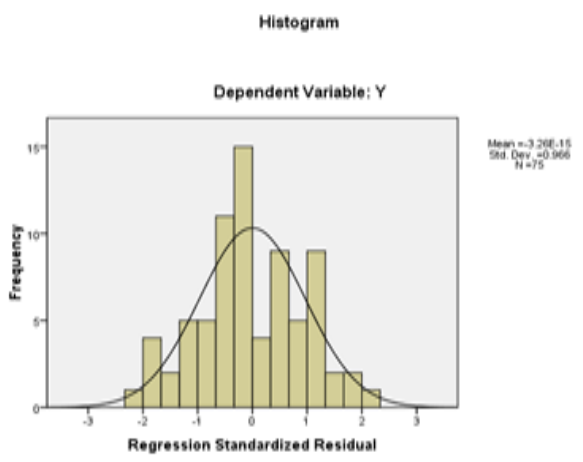

Gambar 1. Uji Normalitas Data

Dengan melihat tampilan grafik histogram dapat disimpulkan bahwa pola distribusi data adalah normal dengan gambar seperti lonceng yang yang tegak tanpa adanya kecondongan ke keri atau ke kanan

\section{Uji Multikolinearitas}

Tabel 1. Uji Multikolinearitas

\begin{tabular}{llrrrrrr}
\hline & & \multicolumn{2}{c}{ Unstandarized } & \multicolumn{2}{c}{ Standarized } & \multicolumn{3}{c}{ Collinearity } \\
\cline { 2 - 8 } \multicolumn{1}{l}{ Model } & \multicolumn{1}{c}{ B } & \multicolumn{1}{c}{ Std. } & \multicolumn{1}{c}{ Coefficients } & \multicolumn{1}{c}{ t } & Sig & Tolerance & \multicolumn{1}{c}{ VIF } \\
\hline 1 & (Constant) & & \multicolumn{1}{c}{ Error } & \multicolumn{1}{c}{ Beta } \\
X1 & 4.764 & 2.520 & .204 & 1.890 & .063 & .193 & 5.169 \\
& .096 & .118 & .073 & 1.784 & .097 & .874 & 1.145 \\
X2 & .425 & .076 & .300 & 1.875 & .207 & .199 & 5.019 \\
X3 & .268 & .169 & .283 & 2.515 & .006 & .285 & 3.505 \\
X4 & .602 & .097 & .613 & 6.229 & .000 & .293 & 3.409 \\
\hline
\end{tabular}

a. Dependent Variable: $Y$

Berdasarkan hasil pengolahan pada tabel menunjukkan nilai VIF dan tolerance semua variabel dalam penelitian ini tidak mengalami multikolinearitas. Hal ini ditunjukkan oleh nilai VIF ketiga variabel tersebut yang besarnya kurang dari 10, dan nilai tolerancejauh melebihi angka 0,1 (Ghozali, 2007:26). Hasil tersebut menunjukkan bahwa dalam model regresi ini seluruh variable bebas tidak terjadi masalah multikolinearitas.

\section{Uji Heteroskedastisitas}

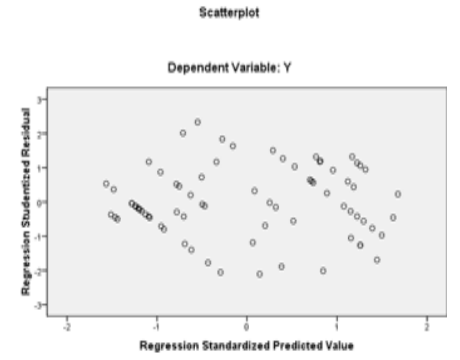

Gambar 2. Uji Heteroskedastisitas

Gambar 2 menunjukkan bahwa titiktitik yang dihasilkan menyebar secara acak dan tidak membentuk suatu pola atau trend garis tertentu. Gambar di atas juga 
menunjukkan bahwa sebaran data ada di sekitar titik nol. Hasil pengujian ini menunjukkan bahwa model regresi ini bebas dari masalah heteroskedastisitas, dengan perkataan lain: variabel-variabel yang akan diuji dalam penelitian ini bersifat homokedastis.

\section{Analisis Regresi Linier Berganda}

Tabel 2. Analisis Regresi Linier Berganda

\begin{tabular}{|c|c|c|c|c|c|c|c|c|}
\hline \multirow{2}{*}{\multicolumn{2}{|c|}{ Model }} & \multicolumn{2}{|c|}{ Unstandarized } & \multicolumn{3}{|l|}{ Standarized } & \multicolumn{2}{|c|}{ Collinearity } \\
\hline & & B & Std. & Coefficients & $\mathbf{t}$ & Sig & Tolerance & VIF \\
\hline 1 & (Constant) & & Error & Beta & & & & \\
\hline & $\mathrm{X} 1$ & 4.764 & 2.520 & .204 & 1.890 & .063 & 193 & 5.169 \\
\hline & $\mathrm{X} 2$ & .096 & .118 & .073 & 1.784 & .097 & .874 & 1.145 \\
\hline & X3 & .425 & .076 & .300 & 1.875 & .207 & 199 & 5.019 \\
\hline & X4 & .268 & 169 & .283 & 2.515 & .006 & .285 & 3.505 \\
\hline & $\times 5$ & .602 & .097 & .613 & 6.229 & .000 & .293 & 3.409 \\
\hline
\end{tabular}

Berdasarkan Tabel 2 di atas, maka persamaan regresi linier berganda dalam penelitian ini adalah: $\mathrm{Y}=$ $4.764+0,198 \mathrm{X}_{1}+0,096 \mathrm{X}_{2}+0,425 \mathrm{X}_{3}+0,268 \mathrm{X}_{4}$ $+0,602 \mathrm{X}_{5}+\mathrm{e}$

1. Pada model regresi ini, nilai konstanta yang tercantum sebesar 4.764 dapat diartikan jika variabel bebas dalam model diasumsikan sama dengan nol, secara rata-rata variabel diluar model tetap akan meningkatkan kepuasan pengunjung kolam renang sebesar 4.764 satu-satuan atau dengan kata lain jika bukti fisik, kehandalan, daya tanggap, jaminan dan empati tidak ditingkatkan, maka kepuasan pelanggan masih sebesar 4.764 satuan.

2. Nilai besaran koefisien regresi $\beta_{1}$ sebesar 0,198 pada penelitian ini dapat diartikan bahwa variabel bukti fisik $\left(\mathrm{X}_{1}\right)$ berpengaruh positif dengan kepuasan pengunjung. Hal ini bahwa ketika bukti fisik mengalami satu satuan, maka kepuasan pengunjung pada kolam renang bengawan solo maka kepuasan pengunjung akan mengalami peningkatan sebesar 0,198 satuan.

3. Nilai besaran koefisien regresi $\beta_{2}$ sebesar 0,096 pada penelitian ini dapat diartikan bahwa variabel kehandalan
$\left(\mathrm{X}_{2}\right)$ berpengaruh positif dengan kepuasan pengunjung. Hal ini bahwa ketika kehandalan mengalami satu satuan, maka kepuasan pengunjung pada kolam renang bengawan solo maka kepuasan pengunjung akan mengalami peningkatan sebesar 0,096 satuan.

4. Nilai besaran koefisien regresi $\beta_{3}$ sebesar 0,425 pada penelitian ini dapat diartikan bahwa variabel daya tanggap $\left(\mathrm{X}_{3}\right)$ berpengaruh positif dengan kepuasan pengunjung. Hal ini bahwa ketika daya tanggap mengalami satu satuan, maka kepuasan pengunjung pada kolam renang bengawan solo maka kepuasan pengunjung akan mengalami peningkatan sebesar 0,425 satuan.

5. Nilai besaran koefisien regresi $\beta_{4}$ sebesar 0,268 pada penelitian ini dapat diartikan bahwa variabel jaminan $\left(\mathrm{X}_{4}\right)$ berpengaruh positif dengan kepuasan pengunjung. Hal ini bahwa ketika jaminan mengalami satu satuan, maka kepuasan pengunjung pada kolam renang bengawan solo maka kepuasan pengunjung akan mengalami peningkatan sebesar 0,268 satuan.

6. Nilai besaran koefisien regresi $\beta_{5}$ sebesar 0,602 pada penelitian ini dapat 
diartikan bahwa variabel empati $\left(\mathrm{X}_{5}\right)$ berpengaruh positif dengan kepuasan pengunjung. Hal ini bahwa ketika empati mengalami satu satuan, maka kepuasan pengunjung pada kolam renang bengawan solo maka kepuasan pengunjung akan mengalami peningkatan sebesar 0,268 satuan.

\section{Pengujian Hipotesis}

Tabel 3. Hasil Uji t

\begin{tabular}{|c|c|c|c|c|c|c|c|c|}
\hline \multirow{2}{*}{\multicolumn{2}{|c|}{ Model }} & \multicolumn{2}{|c|}{ Unstandarized } & \multicolumn{3}{|l|}{ Standarized } & \multicolumn{2}{|c|}{ Collinearity } \\
\hline & & \multirow[t]{2}{*}{ B } & \multirow{2}{*}{$\begin{array}{l}\text { Std. } \\
\text { Error }\end{array}$} & \multirow{2}{*}{$\begin{array}{c}\text { Coefficients } \\
\text { Beta }\end{array}$} & \multirow[t]{2}{*}{$t$} & \multirow[t]{2}{*}{ Sig } & \multirow{2}{*}{ Tolerance } & \multirow{2}{*}{ VIF } \\
\hline 1 & (Constant) & & & & & & & \\
\hline & $\mathrm{X} 1$ & 4.764 & 2.520 & .204 & 1.890 & .063 & .193 & 5.169 \\
\hline & $\mathrm{X} 2$ & .096 & .118 & .073 & 1.784 & .097 & .874 & 1.145 \\
\hline & $\mathrm{X} 3$ & .425 & .076 & .300 & 1.875 & 207 & 199 & 5.019 \\
\hline & X4 & .268 & .169 & .283 & 2.515 & .006 & .285 & 3.505 \\
\hline & $\times 5$ & .602 & .097 & .613 & 6.229 & .000 & .293 & 3.409 \\
\hline
\end{tabular}

c. Dependent Variable: $Y$

Dari Tabel 3 di atas diketahui bahwa:

1. Nilai Signifikansinya untuk variabel bukti fisik $(0,097)$ lebih besar dibandingkan dengan dari alpha 5\% $(0,05)$ atau $t$ hitung $=1,748(n-5=75-$ 5=70) $>\mathrm{t}$ tabel 1,667 Berdasarkan hasil yang diperoleh maka menolak H0 dan menerima. Ha untuk variabel bukti fisik. Dengan demikian, secara parsial bahwa variabel bukti fisik berpengaruh positif terhadap kepuasan pengunjung pada Kolam Renang Bengawan Solo Brandan. Hal ini berarti bahwa bukti sangat penting dalam meningkatkan kepuasan pengunjung pada Kolam Renang Bengawan Solo Brandan.

2. Nilai Signifikansinya untuk variabel kehandalan $(0,207)$ lebih besar dibandingkan dengan dari alpha 5\% $(0,05)$ atau $t$ hitung $=1,875(\mathrm{n}-5=75$ $5=70)>\mathrm{t}$ tabel 1,667 Berdasarkan hasil yang diperoleh maka menolak H0 dan menerima. Ha untuk variabel kehandalan. Dengan demikian, secara parsial bahwa variabel kehandalan berpengaruh positif terhadap kepuasan pengunjung pada Kolam Renang Bengawan Solo Brandan. Hal ini berarti bahwa bukti sangat penting dalam meningkatkan kepuasan pengunjung pada Kolam Renang Bengawan Solo Brandan.

3. Nilai Signifikansinya untuk variabel daya tanggap $(0,014)$ lebih kecil dibandingkan dengan dari alpha 5\% $(0,05)$ atau $t$ hitung $=2,515(\mathrm{n}-5=75$ $5=70)>t$ tabel 1,667 Berdasarkan hasil yang diperoleh maka menolak $\mathrm{HO}$ dan menerima. Ha untuk variabel daya tanggap. Dengan demikian, secara parsial bahwa variabel daya tanggap berpengaruh positif dan signifikan terhadap kepuasan pengunjung pada Kolam Renang Bengawan Solo Brandan. Hal ini berarti bahwa daya tanggap sangat penting dalam meningkatkan kepuasan pengunjung pada Kolam Renang Bengawan Solo Brandan.

4. Nilai Signifikansinya untuk variabel jaminan (0,006) lebih kecil dibandingkan dengan dari alpha 5\% $(0,05)$ atau $t$ hitung $=2,838(\mathrm{n}-5=75$ $5=70)>t$ tabel 1,667 Berdasarkan hasil yang diperoleh maka menolak $\mathrm{H} 0$ dan menerima. Ha untuk variabel jaminan. Dengan demikian, secara parsial bahwa variabel jaminan berpengaruh positif dan signifikan terhadap kepuasan pengunjung pada Kolam Renang Bengawan Solo Brandan. Hal ini berarti 
bahwa jaminan sangat penting dalam meningkatkan kepuasan pengunjung pada Kolam Renang Bengawan Solo Brandan.

5. Nilai Signifikansinya untuk variabel empati $(0,000)$ lebih kecil dibandingkan dengan dari alpha $5 \%(0,05)$ atau $\mathrm{t}$ hitung $=6,229(\mathrm{n}-5=75-5=70)>\mathrm{t}$ tabel 1,667 Berdasarkan hasil yang diperoleh maka menolak $\mathrm{H} 0$ dan menerima. $\mathrm{Ha}$ untuk variabel empati. Dengan demikian, secara parsial bahwa variabel empati berpengaruh positif dan signifikan terhadap kepuasan pengunjung pada Kolam Renang Bengawan Solo Brandan. Hal ini berarti bahwa empati sangat penting dalam meningkatkan kepuasan pengunjung pada Kolam Renang Bengawan Solo Brandan.

\section{Uji Simultan (Uji F)}

Tabel 4. Hasil Uji F

\begin{tabular}{llrrrrr}
\hline & Model & Sum of Square & df & Mean Square & F & Sig \\
\hline 1 & Regression & 496.414 & 5 & 99.283 & 56.554 & $.000^{\mathrm{a}}$ \\
& Residual & 121.133 & 69 & 1.756 & & \\
Total & 617.547 & 74 & & & \\
\hline
\end{tabular}

a. Predictors: (Constanst), X5, X2, X3, X4, X1

b. DependentVariabel: $Y$

Pada Tabel 4 hasil uji F (simultan) dalam penelitian ini, diketahui nilai signifikansi 0,000. Dimana disyaratkan nilai signifikansi $\mathrm{F}$ lebih kecil dari 5\% atau 0,05 atau nilai $\mathrm{F}$ hitung $=56,554>\mathrm{F}$ tabel 2,50 $(\mathrm{df} 1=\mathrm{k}-1=5-1=4)$ sedangkan $(\mathrm{df} 2=\mathrm{n}-\mathrm{k}$ (n-k-1=75-4-1=70). Dengan demikian dapat disimpulkan bahwa semua variabel independen yaitu bukti fisik, kehandalan, daya tanggap, jaminan dan empati berpengaruh positif dan signifikan terhadap kepuasan pengunjung pada Kolam Renang Bengawan Solo Pangkalan Brandan. Hal ini berarti bahwa variabel bukti fisik, kehandalan, daya tanggap, jaminan dan empati sangat perlu ditingkatkan karena secara simultan atau bersama-sama memiliki pengaruh dalam meningktkan rasa kepuasan pengunjung pada Kolam Renang Bengawan Solo Pangkalan Brandan.

\section{Koefisien Determinasi $\left(\mathbf{R}^{\mathbf{2}}\right)$}

Tabel 5. Hasil Koefisien Determinasi

\begin{tabular}{|c|c|c|c|c|}
\hline Model & $\mathbf{R}$ & R Square & $\begin{array}{c}\text { Adjusted R } \\
\text { Square }\end{array}$ & $\begin{array}{l}\text { Std. Error of the } \\
\text { Estimate }\end{array}$ \\
\hline 1 & $.897^{\mathrm{a}}$ & .804 & .790 & 1.32497 \\
\hline
\end{tabular}

Berdasarkan Tabel diperoleh nilai regresi korelasi sebesar 0,897 , artinya secara bersama-sama bukti fisik, kehandalan, daya tanggap, jaminan dan empati terhadap kepuasan pengunjung mampu menjelaskan pada taraf yang erat dan positif. Kemudian koefisien determinasi $\left(\mathrm{R}^{2}\right)$ sebesar 0.804 $(80,4 \%)$. Sehingga dapat dikatakan bahwa $80,4 \%$ variasi variabel terikat yaitu bukti fisik, kehandalan, daya tanggap, jaminan dan empati pada model dapat menjelaskan kepuasan pengunjung sedangkan sisanya 
sebesar 19,6\% dipengaruhi oleh variabel lain di luar model.

\section{Pembahasan}

Pengaruh Bukti Fisik Terhadap Kepuasan Pengunjung Pada Kolam Renang Bengawan Solo Pangkalan Brandan

Berdasarkan anaslisis secara parsial bahwa bukti fisik memiliki pengaruh yang positif terhadap kepuasan pelanggan. Hal ini dapat dibuktikan dari hasil uji parsial, dimana nilai signifikansinya untuk variabel bukti fisik $(0,097)$ lebih besar dibandingkan dengan dari alpha $5 \%(0,05)$ atau t hitung $=$ $1,748(\mathrm{n}-5=75-5=70)>\mathrm{t}$ tabel 1,667 Berdasarkan hasil yang diperoleh maka menolak H0 dan menerima. Ha untuk variabel bukti fisik. Dengan demikian, secara parsial bahwa variabel bukti fisik berpengaruh positif terhadap kepuasan pengunjung pada Kolam Renang Bengawan Solo Brandan. Hal ini berarti bahwa bukti sangat penting dalam meningkatkan kepuasan pengunjung pada Kolam Renang Bengawan Solo Brandan. Hasil penelitian sesuai dengan penelitian Widjayanti dan Budiadi (2016) yang menyatakan bahwa bukti fisik berpengaruh positif dan signifkan terhadap kepuasan pengunjung kolam renang. Selain itu penelitian ini juga mendukung penelitian Rahman dan Harti (2016) yang menyatakan bahwa bukti fisik berpengaruh positif dan signifikan terhadap kepuasan pengunjung. Sehingga apabila bukti fisik ditingkatkan maka akan meningkat kepuasan pengunjung kolam renang.maka akan meningkat kepuasan pengunjung kolam renang.

\section{Pengaruh Kehandalan Terhadap Kepuasan Pengunjung Pada Kolam Renang Bengawan Solo Pangkalan Brandan}

Berdasarkan analisis secara parsial diketahui bahwa dimana nilai signifikansinya untuk variabel kehandalan
$(0,207)$ lebih besar dibandingkan dengan dari alpha $5 \%(0,05)$ atau $t$ hitung $=1,875$ $(\mathrm{n}-5=75-5=70)>\mathrm{t}$ tabel 1,667 Berdasarkan hasil yang diperoleh maka menolak $\mathrm{H} 0$ dan menerima. Ha untuk variabel kehandalan. Dengan demikian, secara parsial bahwa variabel kehandalan berpengaruh positif terhadap kepuasan pengunjung pada Kolam Renang Bengawan Solo Brandan. Hal ini berarti bahwa bukti sangat penting dalam meningkatkan kepuasan pengunjung pada Kolam Renang Bengawan Solo Brandan. Hasil penelitian sesuai dengan penelitian Widjayanti dan Budiadi (2016) yang menyatakan bahwa kehandalan berpengaruh positif dan signifkan terhadap kepuasan pengunjung kolam renang. Selain itu penelitian ini juga mendukung penelitian Rahman dan Harti (2016) yang menyatakan bahwa kehandalan berpengaruh positif dan signifikan terhadap kepuasan pengunjung. Sehingga apabila kehandalan ditingkatkan maka akan meningkat kepuasan pengunjung kolam renang.

\section{Pengaruh Daya Tanggap Terhadap Kepuasan Pengunjung Pada Kolam Renang Bengawan Solo Pangkalan Brandan}

Berdasarkan analisis secara parsial diketahui bahwa dimana nilai signifikansinya untuk variabel daya tanggap $(0,014)$ lebih kecil dibandingkan dengan dari alpha $5 \%(0,05)$ atau $t$ hitung $=2,515$ $(\mathrm{n}-5=75-5=70)>\mathrm{t}$ tabel 1,667 Berdasarkan hasil yang diperoleh maka menolak $\mathrm{H} 0$ dan menerima. Ha untuk variabel daya tanggap. Dengan demikian, secara parsial bahwa variabel daya tanggap berpengaruh positif dan signifikan terhadap kepuasan pengunjung pada Kolam Renang Bengawan Solo Brandan. Hal ini berarti bahwa daya tanggap sangat penting dalam meningkatkan kepuasan pengunjung pada Kolam Renang Bengawan Solo Brandan. Hasil penelitian sesuai dengan penelitian Widjayanti dan Budiadi (2016) yang menyatakan bahwa daya tanggap berpengaruh positif dan 
signifkan terhadap kepuasan pengunjung kolam renang. Selain itu penelitian ini juga mendukung penelitian Rahman dan Harti (2016) yang menyatakan bahwa daya tanggap berpengaruh positif dan signifikan terhadap kepuasan pengunjung. Sehingga apabila kehandalan ditingkatkan maka akan meningkat kepuasan pengunjung kolam renang.

\section{Pengaruh Jaminan Terhadap Kepuasan Pengunjung Pada Kolam Renang Bengawan Solo Pangkalan Brandan}

Berdasarkan analisis secara parsilan diketahui bahwa nilai signifikansinya untuk variabel jaminan $(0,006)$ lebih kecil dibandingkan dengan dari alpha 5\% $(0,05)$ atau $\mathrm{t}$ hitung $=2,838(\mathrm{n}-5=75-5=70)>\mathrm{t}$ tabel 1,667 Berdasarkan hasil yang diperoleh maka menolak H0 dan menerima. Ha untuk variabel jaminan. Dengan demikian, secara parsial bahwa variabel jaminan berpengaruh positif dan signifikan terhadap kepuasan pengunjung pada Kolam Renang Bengawan Solo Brandan. Hal ini berarti bahwa jaminan sangat penting dalam meningkatkan kepuasan pengunjung pada Kolam Renang Bengawan Solo Brandan. Hasil penelitian sesuai dengan penelitian Widjayanti dan Budiadi (2016) yang menyatakan bahwa jaminan berpengaruh positif dan signifkan terhadap kepuasan pengunjung kolam renang. Selain itu penelitian ini juga mendukung penelitian Rahman dan Harti (2016) yang menyatakan bahwa jaminan berpengaruh positif dan signifikan terhadap kepuasan pengunjung. Sehingga apabila jaminan ditingkatkan maka akan meningkat kepuasan pengunjung kolam renang.

\section{Pengaruh Empati Terhadap Kepuasan Pengunjung Pada Kolam Renang Bengawan Solo Pangkalan Brandan}

Berdasarkan analisis secara parsilan diketahui bahwa nilai signifikansinya untuk variabel empati $(0,000)$ lebih kecil dibandingkan dengan dari alpha 5\% $(0,05)$ atau $\mathrm{t}$ hitung $=6,229(\mathrm{n}-5=75-5=70)>\mathrm{t}$ tabel 1,667 Berdasarkan hasil yang diperoleh maka menolak $\mathrm{H} 0$ dan menerima. $\mathrm{Ha}$ untuk variabel empati. Dengan demikian, secara parsial bahwa variabel empati berpengaruh positif dan signifikan terhadap kepuasan pengunjung pada Kolam Renang Bengawan Solo Brandan. Hal ini berarti bahwa empati sangat penting dalam meningkatkan kepuasan pengunjung pada Kolam Renang Bengawan Solo Brandan. Hasil penelitian sesuai dengan penelitian Widjayanti dan Budiadi (2016) yang menyatakan bahwa empati berpengaruh positif dan signifkan terhadap kepuasan pengunjung kolam renang. Selain itu penelitian ini juga mendukung penelitian Rahman dan Harti (2016) yang menyatakan bahwa empati berpengaruh positif dan signifikan terhadap kepuasan pengunjung. Sehingga apabila empati ditingkatkan maka akan meningkat kepuasan pengunjung kolam renang.

Pengaruh Bukti Fisik, Kehandalan, Daya Tanggap, Jaminan dan Empati Terhadap Kepuasan Pengunjung Pada Kolam Renang Bengawan Solo Pangkalan Brandan

Berdasarkan analisis secara simultan diketahui bahwa nilai signifikansi 0,000 . Dimana disyaratkan nilai signifikansi $\mathrm{F}$ lebih kecil dari $5 \%$ atau 0,05 atau nilai $F$ hitung $=56,554>\mathrm{F}$ tabel 2,50 $(\mathrm{df} 1=\mathrm{k}-1=5$ $1=4)$ sedangkan $(\mathrm{df} 2=\mathrm{n}-\mathrm{k}(\mathrm{n}-\mathrm{k}-1=75-4$ $1=70$ ). Dengan demikian dapat disimpulkan bahwa semua variabel independen yaitu bukti fisik, kehandalan, daya tanggap, jaminan dan empati berpengaruh positif dan signifikan terhadap kepuasan pengunjung pada Kolam Renang Bengawan Solo Pangkalan Brandan. Hal ini berarti bahwa variabel bukti fisik, kehandalan, daya tanggap, jaminan dan empati sangat perlu ditingkatkan karena secara simultan atau bersama-sama memiliki pengaruh dalam meningktkan rasa kepuasan pengunjung pada Kolam Renang Bengawan Solo 
Pangkalan Brandan. Hasil penelitian sesuai dengan penelitian Widjayanti dan Budiadi (2016) yang menyatakan bahwa bukti fisik, kehandalan, daya tanggap, jaminan dan empati itu penelitian ini juga mendukung penelitian Rahman dan Harti (2016) yang menyatakan bahwa bukti fisik, kehandalan, daya tanggap, jaminan dan empati berpengaruh positif dan signifikan terhadap kepuasan pengunjung. Sehingga apabila bukti fisik, kehandalan, daya tanggap, jaminan dan empati ditingkatkan maka akan meningkat kepuasan pengunjung kolam renang.

\section{SIMPULAN}

Nilai Signifikansinya untuk variabel bukti fisik $(0,097)$ lebih besar dibandingkan dengan dari alpha $5 \%(0,05)$ atau thitung $=$ $1,748(\mathrm{n}-5=75-5=70)>\mathrm{t}$ tabel 1,667 Berdasarkan hasil yang diperoleh maka menolak H0 dan menerima. Ha untuk variabel bukti fisik. Dengan demikian, secara parsial bahwa variabel bukti fisik berpengaruh positif terhadap kepuasan pengunjung pada Kolam Renang Bengawan Solo Brandan. Hal ini berarti bahwa bukti sangat penting dalam meningkatkan kepuasan pengunjung pada Kolam Renang Bengawan Solo Brandan. Nilai Signifikansinya untuk variabel kehandalan $(0,207)$ lebih besar dibandingkan dengan dari alpha $5 \%(0,05)$ atau $t$ hitung $=1,875$ $(\mathrm{n}-5=75-5=70)>\mathrm{t}$ tabel 1,667 Berdasarkan hasil yang diperoleh maka menolak H0 dan menerima. Ha untuk variabel kehandalan. Dengan demikian, secara parsial bahwa variabel kehandalan berpengaruh positif terhadap kepuasan pengunjung pada Kolam Renang Bengawan Solo Brandan. Hal ini berarti bahwa bukti sangat penting dalam meningkatkan kepuasan pengunjung pada Kolam Renang Bengawan Solo Brandan.

1. Nilai Signifikansinya untuk variabel daya tanggap $(0,014)$ lebih kecil dibandingkan dengan dari alpha $5 \%(0,05)$ atau thitung $=$ $2,515(\mathrm{n}-5=75-5=70)>\mathrm{t}$ tabel 1,667 Berdasarkan hasil yang diperoleh maka menolak H0 dan menerima Ha untuk variabel daya tanggap. Dengan demikian, secara parsial bahwa variabel daya tanggap berpengaruh positif dan signifikan terhadap kepuasan pengunjung pada Kolam Renang Bengawan Solo Brandan. Hal ini berarti bahwa daya tanggap sangat penting dalam meningkatkan kepuasan pengunjung pada Kolam Renang Bengawan Solo Brandan. Nilai Signifikansinya untuk variabel jaminan $(0,006)$ lebih kecil dibandingkan dengan dari alpha $5 \%(0,05)$ atau t hitung $=$ $2,838(\mathrm{n}-5=75-5=70)>\mathrm{t}$ tabel 1,667 Berdasarkan hasil yang diperoleh maka menolak H0 dan menerima. Ha untuk variabel jaminan. Dengan demikian, secara parsial bahwa variabel jaminan berpengaruh positif dan signifikan terhadap kepuasan pengunjung pada Kolam Renang Bengawan Solo Brandan. Hal ini berarti bahwa jaminan sangat penting dalam meningkatkan kepuasan pengunjung pada Kolam Renang Bengawan Solo Brandan. Nilai Signifikansinya untuk variabel empati $(0,000)$ lebih kecil dibandingkan dengan dari alpha $5 \%(0,05)$ atau $t$ hitung $=6,229$ $(\mathrm{n}-5=75-5=70)>\mathrm{t}$ tabel 1,667 Berdasarkan hasil yang diperoleh maka menolak $\mathrm{H} 0$ dan menerima. Ha untuk variabel empati. Dengan demikian, secara parsial bahwa variabel empati berpengaruh positif dan signifikan terhadap kepuasan pengunjung pada Kolam Renang Bengawan Solo Brandan. Hal ini berarti bahwa empati sangat penting dalam meningkatkan kepuasan pengunjung pada Kolam Renang Bengawan Solo Brandan. Kualitas pelayanan pada Kolam Renang Bengawan Solo Pangkalan Brandan sudah baik, akan tetapi kualitas pelayanan pada unsur daya tanggap, jaminan dan empati sebaiknya terus ditingkatkan karena ketiga variabel tersbeut memiliki pengaruh positif dan signifikan terhadap kepuasan pengunjung kolam renang. Kolam Kolam Renang Bengawan Solo Pangkalan Brandan diharapkan bukan hanya memperbaiki dari segi kualitas pelayanan, melainkan juga dari 
segi fasilitas pada kolam renang juga terus ditingkatkan khususnya dalam hal meningkatkan rasa kepuasan pengunjung.

\section{REFERENSI}

Daryanto, 2011, Sari Kuliah Manajemen Pemasaran, PT. Sarana Tutorial Nurani Sejahtera, Bandung. Jasfar, Farida, 2005, Manajemen Jasa, PT. Ghalia Indonesia, Bandung.

Kotler, Philip dan Kevin Lane Keller.2008. Manajemen Pemasaran. Jilid 13. Edisi 1 Erlangga. Jakarta.

Laksana, Fajar, 2008, Manajemen Pemasaran, PT. Graha Ilmu, Yogyakarta.

Nazir. Moh, 2009, Metode Penelitian. Penerbit PT. Ghalia Indonesia. Bandung.

Rahman Yusli Fadlika dan Harti, 2016, Pengaruh Kualitas Layanan Dan Harga Terhadap Kepuasan Konsumen Di Wisata Kolam Renang Teuku Umar Bojonegoro (Studi Pada Mahasiswa Universitas Negeri Surabaya), Prodi Pend.Tata Niaga, Jurusan Pend.Ekonomi, Fakultas Ekonomi, Universitas Negeri Surabaya, Kampus Ketintang Surabaya.

Riduan, Statistik, 2009, PT. Elex Media Komputindo. Jakarta.

Rusiadi, et al, 2013, Metode Penelitian. Akuntansi dan Ekonomi Pembangunan. Konsep. Kasus dan Aplikasi SPSS. Eviews. Amos dan Lisrel. Cetakan Pertama USU Press. Medan.

Sugiyono, 2009. Metode Penelitian Kuantitatif dan $R \& D$. Alfabeta. Bandung

Situmorang, Safrizal Helmi, 2011, Bisnis dan Konsep. USU. Medan.

Tjiptono, Fandy, 2007, Strategi Bisnis Pemasaran. Andi. Yogyakarta.

.............. , 2008, Strategi Bisnis Pemasaran. Andi. Yogyakarta.

Wulandari Nur. 2013. Analisis Pengaruh Kualitas Produk, Kualitas Pelayanan dan Loakasi Terhadap Kepuasan Konsumen (Studi Kasus Pada Konsumen Kopikita Semarang). Universitas Diponegoro. Semarang. Widjayanti Rinda dan Budiadi Setiyo, 2016, Pengaruh Kualitas Jasa Terhadap Kepuasan Konsumen Pada Kolam Renang Obyek Wisata Pacet Mini Park, Prodi Pendidikan Tata Niaga, Jurusan Pendidikan Ekonomi, Fakultas Ekonomi Universitas Negeri Surabaya.

Yuri dan Nurcahyo, Rahmat, 2013, TQM Manajemen Kualitas Total dalam Perspektif Teknik Industri, PT Indeks, Jakarta. 